\title{
IŠMANIUOSIUS İRENGINIUS NAUDOJANČIŲ ASMENŲ KAKLINĖS STUBURO DALIES FUNKCIJOS POKYČIŲ VERTINIMAS
}

\section{Deimanta Maksimovaitė, Giedrė Jurgelaitienė}

Lietuvos sporto universitetas

\section{SANTRAUKA}

Tyrimo pagrindimas. Augant išmaniųjų įrenginių naudojimui, padidèjo susirūpinimas griaučiu ir raumenų sistemos problemomis, susijusiomis su ilgalaikiu išmaniujų įrenginių naudojimu (Jung et al., 2016). Ilgai trunkantis ir dažnas išmaniojo ịrenginio naudojimas išlaikant stipriai ị priekị palenktą galvos padètị gali būti vienas iš pagrindinių veiksnių, lemiančių išmaniųjų ịrenginių naudotojų lètinị kaklo ir pečių lanko skausmą (Alfaitouri, Altaboli, 2019).

Tikslas - nustatyti išmaniuosius įrenginius naudojančių asmenų kaklinės stuburo dalies funkcijos pokyčius.

Metodai. Buvo tirti 26 asmenys (14 moterų, 12 vyrų). İvertintas tiriamujų priklausomumas nuo išmaniujų ịrenginių naudojimo, nustatyta kaklinès dalies aktyvių judesių amplitudè ir judesius atliekančių raumenų jèga.

Rezultatai. Kaklinès dalies aktyvių lenkimo, tiesimo, šoninio lenkimo ị kairę ir ị dešinę pusę, rotacijos ị kairę ir i dešinę pusę judesių amplitudès reikšmingai skyrèsi tarp neturinčiu priklausomumo rizikos (NPrR), didelès priklausomumo rizikos (DPrR) ir priklausomumo (Pr) grupiu $(\mathrm{p}<0,05)$. Kaklinės stuburo dalies judesius atliekančių lenkiamujų raumenų jèga Pr grupejje reikšmingai mažesnè nei NPrR grupeje $(\mathrm{p}<0,05)$. Kaklo lenkiamujų raumenų jèga Pr grupejje siekè $6,2 \pm$ $2,5 \mathrm{~kg}, \mathrm{NPrR}$ grupèje $-9,7 \pm 4,1 \mathrm{~kg}$.

Išvados. Asmenų, naudojančių išmaniuosius įrenginius ilgiau nei 3 metus ir turinčių priklausomumą nuo išmaniụjų įrenginių naudojimo, kaklinès dalies aktyvių judesių amplitudès ir lenkiamųjų raumenų jèga reikšmingai mažesnè, lyginant su asmenimis, neturinčiais priklausomumo rizikos ir turinčiais didelę priklausomumo riziką.

Raktažodžiai: išmanieji ịrenginiai, kaklinè stuburo dalis, judesio amplitudè, raumenų jèga, funkcija.

\section{IVADAS}

Per pastarajị dešimtmetị išmaniụjų įrenginių naudotojų skaičius pamažu didejjo visame pasaulyje (Jung et al., 2016). Išmanieji įrenginiai tapo ne tik modernios aukštụjų technologijų ịrangos pavyzdžiu, bet ir kasdiene būtinybe. Išmaniųu įrenginių modelių tobulèjimas prisideda prie dažno išmaniojo telefono naudojimo ir priklausomumo nuo jo (AlAbdulwahab et al., 2017).

Augant išmaniųjų įrenginių naudojimui, padidejo susirūpinimas griaučių ir raumenų sistemos problemomis, susijusiomis su ilgalaikiu išmaniujų telefonų nau-

Copyright (C) 2020 Deimanta Maksimovaité, Giedrė Jurgelaitienė. Published by Lithuanian Sports University.

This is an Open Access article distributed under the terms of the Creative Commons Attribution 4.0 International License, which permits unrestricted use, distribution, and reproduction in any medium, provided the original author and source are credited.. 
dojimu (Jung et al., 2016). Ilgesnis naudojimasis išmaniaisiais įrenginiais tampa netaisyklingos laikysenos, tokios kaip ị priekị palenktos galvos padèties, suapvalintų pečių ar pakumpusios laikysenos priežastimi. Todèl ilgai trunkantis ir dažnas išmaniojo ịrenginio naudojimas išlaikant stipriai ị prieki palenktą galvos padètị gali būti vienas iš pagrindinių veiksnių, lemiančių išmaniųjų telefonų naudotojų lètinị kaklo ir pečių lanko skausmą (Alfaitouri, Altaboli, 2019).

Viena dažniausių lėtinio skausmo atsiradimo priežasčių yra miofascijinis skausmo sindromas (Bron et al., 2011). Miofascijinių trigerinių taškų sukeltas skausmas yra svarbi sveikatos problema, su kuria bent kartą per savo gyvenimą susiduria apie $85 \%$ populiacijos (Jafri, 2014). Asmenys, patiriantys miofascijini skausmo sindromą, susiduria su funkcinès būklès sutrikimais ar suprastejusia gyvenimo kokybe.

Tyrimo tikslas - nustatyti išmaniuosius įrenginius naudojančiu asmenų kaklinès stuburo dalies funkcijos pokyčius.

\section{METODAI}

Tiriamieji. Buvo tirti 26 asmenys (14 moterų, 12 vyrų). Ittraukimo ị tyrimą kriterijai: 18-30 metų amžiaus moterys ir vyrai; išmaniujų įrenginių naudojimas trunka 3 metus ir ilgiau; naudojantis išmaniuoju ịrenginiu visą dieną subjektyviai jaučiamas kaklo ir (ar) pečių lanko skausmas trunka 3 mėnesius ir ilgiau; mažesnis nei 8 valandų sèdèjimas per parą (vertintas tarptautinio fizinio aktyvumo klausimyno trumpaja lietuviška versija); netaisyklinga galvos padètis (protrakcija) (vertinta „Forward head posture“ mobiliąja programèle). Neįtraukimo ị tyrimą kriterijai: anksčiau įvykę kaklo slankstelių lūžiai, „kirčio“ trauma. Pagal išmaniujų įrenginių naudojimo ịpročiu klausimyno rodiklius tiriamieji suskirstyti $\mathfrak{i}$ tris grupes: nèra priklausomumo rizikos $(\mathrm{NPrR})(\mathrm{n}=8)$; didelè priklausomumo rizika $(\mathrm{DPrR})(\mathrm{n}=$ 9); priklausomumo grupè $(\operatorname{Pr})(\mathrm{n}=9)$.

Tyrimo organizavimas ir eiga. Tyrimas pradètas gavus Lietuvos sporto universiteto Bioetikos komisijos leidimą atlikti biomedicinini tyrimą. Tyrimas atliktas laikantis Helsinkio deklaracijos principų. Išmaniuosius ịrenginius naudojantys asmenys $(n=29)$ turèjo užpildyti anketą. Joje buvo pateikti bendri klausimai, susiję su išmaniujų įrenginių naudojimu, ir atrankos kriterijus atitinkantys klausimai. Asmenų ( $\mathrm{n}=26$ ), kurie atitiko nustatytus kriterijus, buvo prašoma užpildyti išmaniųjų ịrenginių naudojimo ịpročių klausimyną. Tuomet vertinamos tiriamujjų aktyvių kaklo judesių amplitudès ir kaklo judesius atliekančių raumenų jèga.

\section{Tyrimo metodai}

Fizinio aktyvumo vertinimas. Kaip vienas iš atrankos kriterijų buvo vertinamas fizinis aktyvumas naudojant tarptautinio fizinio aktyvumo klausimyno trum- 
pają lietuvišką versiją (angl. International Physical Activity Questionnaire-Short Form).

Netaisyklingos galvos padeties (protrakcijos) vertinimas. Kaip vienas iš atrankos kriteriju - netaisyklingos galvos padèties (protrakcijos) vertinimas. Naudojant išmaniojo telefono mobiliają programėlę „Forward head posture“, buvo matuojamas galvos pasvirimo pirmyn kampas.

Subjektyvus išmaniuju ịrenginiu naudojimo ịpročiu vertinimas. Naudotas išmaniuju įrenginių naudojimo ịpročiu klausimynas, sudarytas remiantis priklausomumo nuo išmaniujų telefonų skalès trumpaja versija (angl. Smartphone Addiction Scale-Short Version-SAS-SV) (Kwon et al., 2013).

Kaklinès stuburo dalies aktyviu judesiu amplitudžiu vertinimas. Kaklinès dalies aktyviu judesių amplitudèms vertinti pasirinkti inklinometrijos ir goniometrijos metodai. Aktyvių lenkimo, tiesimo, šoninio lenkimo ị dešinę ir ị kairę judesių amplitudèms matuoti naudotas burbulinis gravitacinis inklinometras (Baseline Bubble Inclinometer, Fabrication Enterprises Inc., USA), o aktyvūs rotacijos ị dešinę ir ị kairę judesiai matuoti standartiniu goniometru (Childs et al., 2008).

Kaklinés stuburo dalies judesius atliekančiu raumenu jègos vertinimas. Kaklinès dalies judesius atliekančiu raumenu jèga vertinta dinamometrijos metodu naudojant rankini dinamometrą (Lafayette Manual Muscle Tester, model 01163, Lafayette Instrument Company, USA). Kaklo lenkiamųjų, tiesiamųjų, šoninių lenkiamujų i kairę ir į dešinę izometrinè raumenų jèga matuota tris kartus darant minutės pertrauką, duomenų analizei atlikti išrinktas geriausias bandymas.

Matematinė statistika. Statistinè duomenų analizè atlikta naudojant Microsoft Office paketo Excel 2010 ir SPSS Statistics 21.0 programas. Analizuojant duomenis pateiktas kiekybinių kintamujų aritmetinis vidurkis () ir standartinis nuokrypis ( $\pm \mathrm{SD})$. Duomenų reikšmingumui tikrinti naudotas neparametrinis dviejų nepriklausomų imčių Mann'o-Whitney'aus kriterijus (U) ir neparametrinis daugiau nei dviejų nepriklausomų imčių Kruskal'io-Wallis'o kriterijus (H). Skirtumas tarp rodiklių statistiškai reikšmingas, kai $\mathrm{p}<0,05$.

\section{TYRIMO REZULTATAI}

Priklausomumas nuo išmaniųjų ịrenginių naudojimo. Priklausomumo nuo išmaniuju įrenginių naudojimo klausimyno rodikliai reikšmingai skyrèsi tarp visų trijų grupių $(\mathrm{p}<0,05)$ (1 pav.). Gauti reikšmingai didesni priklausomumo nuo išmaniujų įrenginių naudojimo rodikliai DPrR grupeje $-28,7 \pm 3,9$ balo ir Pr grupeje $-35,8 \pm 2,5$ balo, lyginant su NPrR grupe $-17,3 \pm 1,9$ balo $(p<0,05)$. Pr grupès klausimyno rodikliai reikšmingai didesni už $\mathrm{DPrR}$ grupès $(\mathrm{p}<0,05)$. Pri- 


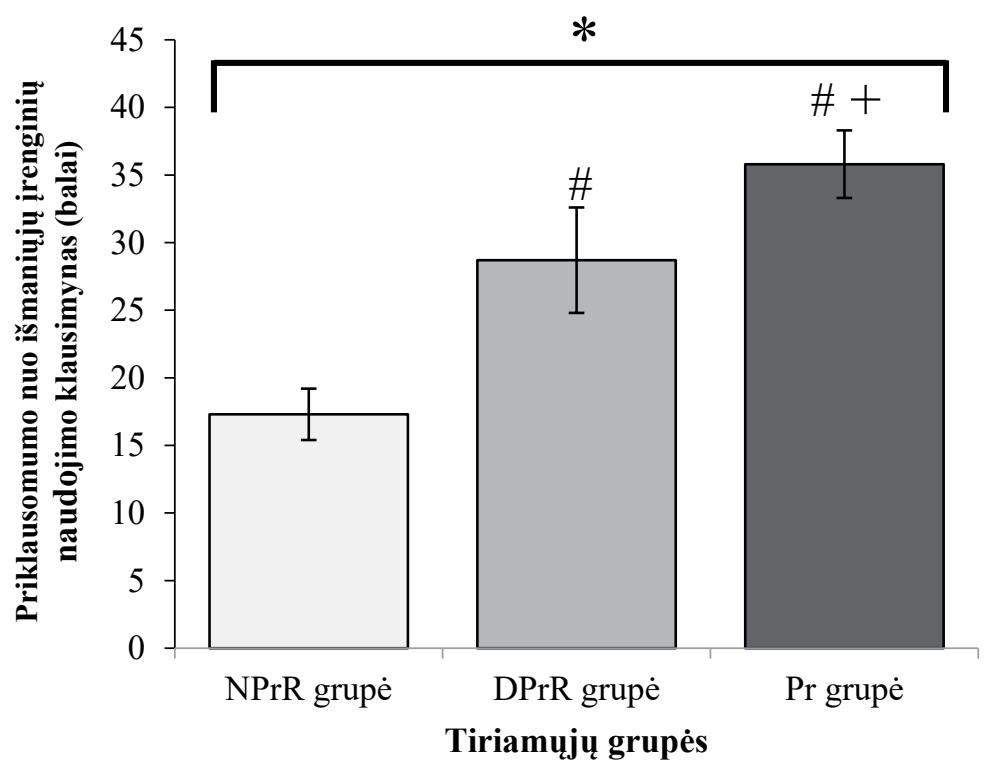

Pastaba. * $-\mathrm{p}<0,05$, lyginant rodiklius tarp grupių; $\#-\mathrm{p}<0,05$, lyginant su NPrR grupès rodikliais; $+-\mathrm{p}<0,05$, lyginant su DPrR grupès rodikliais.

1 pav. Priklausomumo nuo išmaniųjų ịrenginių naudojimo klausimyno rodikliai

klausomumo nuo išmaniujų ịrenginių naudojimo Pr grupëje sieke $35,8 \pm 2,5$ balo, DPrR grupeje $-28,7 \pm 3,9$ balo.

Kaklinės stuburo dalies aktyvių judesių amplitudès. Kaklinės stuburo dalies aktyvių lenkimo (Lenk), tiesimo (Ties), šoninio lenkimo ị kairę (ŠonLK) ir ị dešinę (ŠonLD) pusę, rotacijos ị kairę (RotK) ir ị dešinę (RotD) pusę judesių amplitudès reikšmingai skyrèsi tarp visų trijų grupių $(\mathrm{p}<0,05)(2$ pav.). Gauta reikšmingai mažesnè $(\mathrm{p}<0,05)$ lenkimo judesio amplitudè DPrR grupèje $-45,4 \pm 2,2^{\circ}$ ir $\operatorname{Pr}$ grupeje $-44,9 \pm 4,0^{\circ}$, lyginant su NPrR grupe $-52,9 \pm 4,0^{\circ}$, bei tiesimo judesio DPrR grupejje $-50,9 \pm 2,7^{\circ}$ ir Pr grupeje $-50,8 \pm 4,8^{\circ}$, palyginus su NPrR grupe $-58,0 \pm 2,7^{\circ}$. DPrR ir Pr grupių šoninio lenkimo į kairę ir ị dešinę bei rotacijos i kairę ir ị dešinę judesių amplitudès reikšmingai mažesnès nei NPrR grupès ( $\mathrm{p}<$ 0,05). Šoninio lenkimo ị kairę judesio amplitudè DPrR grupeje siekè $33,8 \pm 3,8^{\circ}$, Pr grupèje $-30,8 \pm 5,1^{\circ}, \mathrm{NPrR}$ grupèje $-37,5 \pm 2,2^{\circ}$, šoninio lenkimo ị dešinę judesio amplitude DPrR grupèje buvo $35,7 \pm 4,0^{\circ}$, Pr grupeje $-32,8 \pm 4,2^{\circ}$, o NPrR grupejje $-39,0 \pm 1,8^{\circ}$. Tuo tarpu rotacijos ị kairę judesio amplitudè DPrR grupeje siekè $48,3 \pm 3,6^{\circ}, \operatorname{Pr}$ grupeje $-45,4 \pm 6,2^{\circ}, \mathrm{NPrR}$ grupeje $-54,6 \pm 5,9^{\circ}$, o rotacijos 


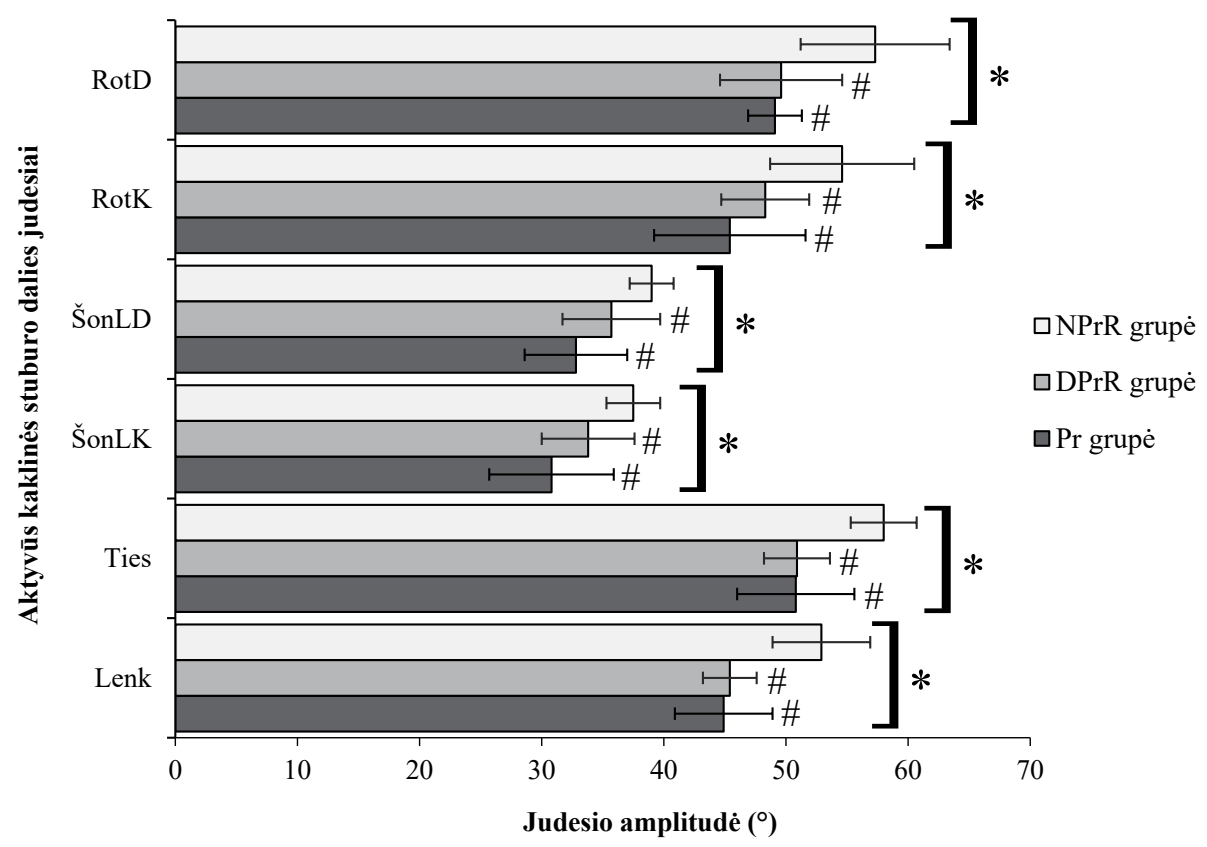

Pastaba. * $-\mathrm{p}<0,05$, lyginant rodiklius tarp grupių; $\#-\mathrm{p}<0,05$, lyginant su NPrR grupès rodikliais.

Lenk - lenkimas, Ties - tiesimas, ŠonLK - šoninis lenkimas į kairę pusę,

ŠonLD - šoninis lenkimas į dešinę pusę,

RotK - rotacija ị kairę pusę, RotD - rotacija ị dešinę pusę.

2 pav. Kaklinès stuburo dalies aktyvių judesių amplitudžių rodiklių palyginimas tarp grupių

ị dešinę amplitudè DPrR grupèje buvo 49,6 $\pm 5,0^{\circ}$, Pr grupèje $-49,1 \pm 2,2^{\circ}, \mathrm{NPrR}$ grupèje $-57,3 \pm 6,1^{\circ}$.

Kaklinès stuburo dalies judesius atliekančių raumenų jẻga. Kaklinès stuburo dalies judesius atliekančių lenkiamųų raumenų jèga (Lenk) Pr grupèje reikšmingai mažesnè nei NPrR grupejje ( $\mathrm{p}<0,05)$ (3 pav.). Kaklo lenkiamujų raumenų jèga Pr grupèje siekè $6,2 \pm 2,5 \mathrm{~kg}$, o NPrR $-9,7 \pm 4,1 \mathrm{~kg}$. 


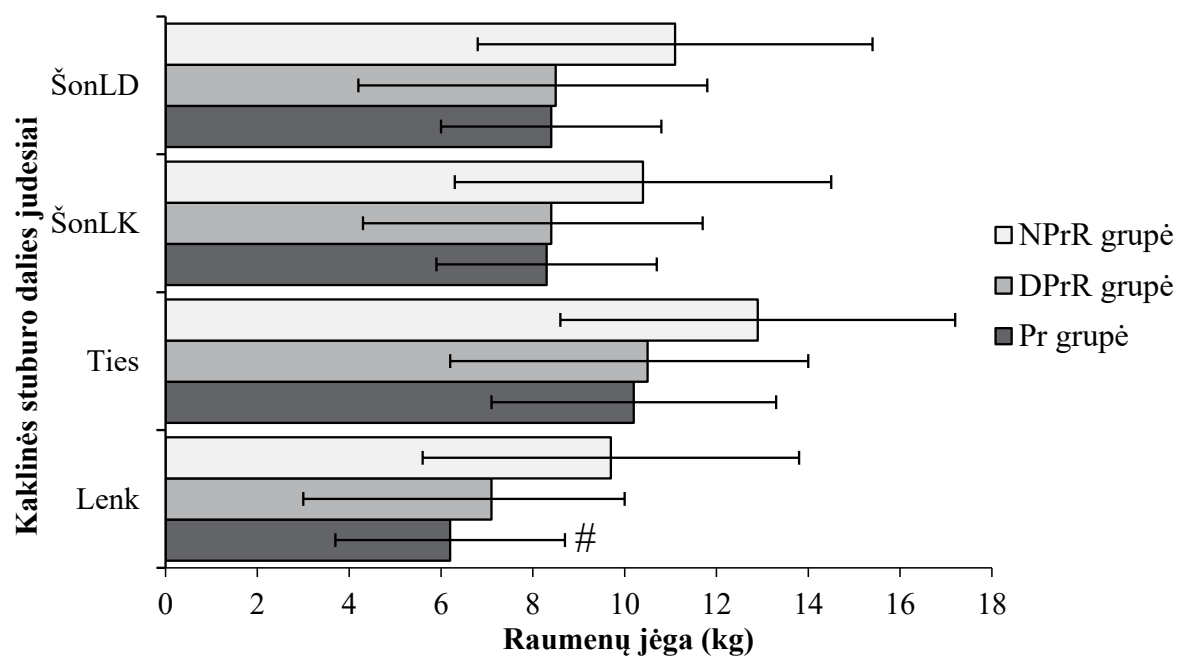

Pastaba. ${ }^{*}-\mathrm{p}<0,05$, lyginant rodiklius tarp grupių. Lenk - lenkimas, Ties - tiesimas, ŠonLK - šoninis lenkimas i

kairę pusę, ŠonLD - šoninis lenkimas į dešinę pusę.

3 pav. Kaklinės stuburo dalies judesius atliekančių raumenų jègos rodiklių palyginimas tarp grupių

\section{REZULTATŲ APTARIMAS}

Atlikus tyrimą nustatyta, kad tarp asmenų, neturinčių priklausomumo rizikos, turinčių didelę priklausomumo riziką ir turinčių priklausomumą nuo išmaniųju įrenginių naudojimo, reikšmingai skyrèsi kaklinės dalies aktyvių judesių amplitudès. Taip pat nustatyta, kad kaklinès dalies lenkiamujų raumenų jèga reikšmingai mažesnè tarp asmenų, turinčių priklausomumą nuo išmaniųu įrenginių naudojimo, lyginant su asmenimis, neturinčiais priklausomumo rizikos.

T. T. Luk'as ir bendraautoriai (2018) ištyre 3211 asmenis, gyvenančius Kinijoje, kuriems buvo daugiau nei 18 metų. Pagal gautus išmaniųjų telefonų naudojimo priklausomumo skalès trumposios versijos rodiklius moterų balai buvo didesni nei vyrų, tačiau abi tiriamos grupès buvo didelès priklausomumo nuo išmaniųjų telefonų naudojimo rizikos. Šio tyrimo rodikliai mažesni už mūsų gautuosius dèl to, kad jų tiriamujų amžiaus riba siekẻ 65 metus ir daugiau, o mes tyrème jaunesnius asmenis - nuo 18 iki 30 metų amžiaus. 
C. Niewiadomski ir kt. (2019), pasitelkę neinvazinę „Codamotion“ judesių analizès sistemą, vertino aktyvios kaklinės stuburo dalies judesių amplitudes. Buvo tirti 97 asmenys, nejaučiantys skausmo, susijusio su kakline dalimi. Jų lenkimo, tiesimo, šoninio lenkimo ir rotacijos ị kairę bei ị dešinę judesių amplitudès didesnès nei mūsų galimai dèl to, kad mes vertinome asmenis, kurie 3 mènesius ir ilgiau jautė pečiu lanko ir (ar) kaklo skausmą, jų galva buvo palinkusi ị priekị bei jų rodiklių matavimo būdas buvo skaitmeninis ir tikslesnis, nei matavimas gravitaciniu inklinometru.

K. T. Vannebo ir kt. (2018) vertino ligoninèje dirbančio personalo ir praktiką atliekančių studentų kaklinès dalies judesius atliekančių raumenų jègą. Buvo tiriama 30 moterų ir 28 vyrai, kurie 3 mènesius iki tyrimo pradžios nejaute pečių lanko, kaklo ir galvos skausmo, o amžiaus vidurkis atitiko mūsų tiriamujų amžių. Kaip ir mes, K. T. Vannebo ir kt. (2018) nustatè, kad didžiausia buvo kaklinės dalies tiesiamujų raumenų jèga, mažiausia - lenkiamujų. Mūsų tyrimo metu nustatyta tiek lenkimo ir tiesimo, tiek šoninio lenkimo ị kairę ir ị dešinę puses raumenų jèga mažesnè nei ligoninèje dirbančio personalo galimai dèl to, kad išmaniuosius ịrenginius naudojantys asmenys turejjo subjektyviai jausti kaklo ir (ar) pečių lanko skausmą 3 ménesius ir ilgiau iki tyrimo pradžios, jų galva buvo palinkusi i prieki ir dèl to susilpnèjo kaklinès dalies raumenys.

\section{IŠVADOS}

$35 \%$ tirtų asmenų, naudojančių išmaniuosius ịrenginius ilgiau nei 3 metus, yra priklausomi nuo išmaniujų i̊renginių naudojimo ir tiek pat asmenų turi didelę riziką priklausyti nuo išmaniujų įrenginių naudojimo.

Asmenų, naudojančių išmaniuosius ịrenginius ilgiau nei 3 metus ir turinčių priklausomumą nuo išmaniụjų ịrenginių naudojimo, kaklinès dalies aktyvių judesių amplitudès ir lenkiamujų raumenų jèga reikšmingai mažesnè, lyginant su asmenimis, neturinčiais priklausomumo rizikos ir turinčiais didelę priklausomumo riziką.

Finansavimas: nėra.

Interesų atskleidimas: nėra.

\section{LITERAT ŪRA}

AlAbdulwahab, S. S., Kachanathu, S. J., AlMotairi, M. S. (2017). Smartphone use addiction can cause neck disability. Musculoskeletal Care, 15 (1), 10-12.

Alfaitouri, S., Altaboli, A. (2019). The effect of posture and duration of smartphone usage on neck flexion angle. Human Factors and Ergonomics Society, 63 (1), 1-5.

Bron, C., de Gast, A., Dommerholt, J. et al. (2011). Treatment of myofascial trigger points in patients with chronic shoulder pain: A randomized, controlled trial. BMC Medicine, 9 (8), 1-14. 
Childs, J. D., Cleland, J. A., Elliott, J. M. et al. (2008). Neck pain: Clinical practice guidelines linked to the international classification of functioning, disability, and health from the orthopaedic section of the American physical therapy association. Journal of Orthopaedic and Sports Physical Therapy, 38 (9), 1-35.

Jafri, S. M. (2014). Mechanisms of myofascial pain. International Scholarly Research Notices, 1-16.

Jung, S. I., Lee, N. K., Kang, K. W., Kim, K., Lee, D. Y. (2016). The effect of smartphone usage time on posture and respiratory function. The Journal of Physical Therapy Science, 28, 186-189.

Kwon, M., Kim, D. J., Cho, H., Yang, S. (2013). The smartphone addiction scale: Development and validation of a short version for adolescents. PLOS One, 8 (12), 1-7.

Luk, T. T., Wang, M. P., Shen, C. et al. (2018). Short version of the smartphone addiction scale in Chinese adults: Psychometric, sociodemographic, and health behavioral correlates. Journal of Behavioral Addictions, 7 (4), 1157-1165.

Niewiadomski, C., Bianco, R. J., Afquir, S., Evin, M., Arnoux, P. J. (2019). Experimental assessment of cervical ranges of motion and compensatory strategies. Chiropractic \& Manual Therapies, 27 (1), 1-9.

Vannebo, K. T., Iversen, V. M., Fimland, M. S., Mork, P. J. (2018). Test-retest reliability of a handheld dynamometer for measurement of isometric cervical muscle strength. Journal of Back and Musculoskeletal Rehabilitation, 31 (3), 557-565.

\title{
EVALUATION OF CHANGES IN THE FUNCTION OF CERVICAL SPINE OF SMART DEVICE USERS
}

\author{
Deimanta Maksimovaitè, Giedrė Jurgelaitienè \\ Lithuanian Sports University
}

\begin{abstract}
Background. With the growing use of smart devices, concerns have also increased about musculoskeletal problems associated with the prolonged use of smart devices (Jung et al., 2016). Prolonged and frequent use of the smart device with the severe head flexion posture could be one of the main contributing factors to the prevalence of neck and shoulders pain symptoms of smart device users (Alfaitouri, Altaboli, 2019).

Aim. The purpose was to determine changes in the function of cervical spine of smart device users.

Methods. Twenty-six individuals participated in the study (14 females, 12 males). Dependency on smart devices, active range of motion and muscle strength of cervical spine were evaluated for the participants.

Results. Active flexion, extension, left and right lateral flexion, left and right rotation range of motion of cervical spine were significantly different between individuals who are at no risk for dependency (NPrR group), at high risk for dependency (DPrR group) and individuals that are dependent (Pr group) on using smart devices. Strength of cervical spine flexor muscles was significantly lower in Pr
\end{abstract}


group than NPrR group $(\mathrm{p}<0.05)$. Strength of neck flexor muscles in Pr group was $6.2 \pm 2.5 \mathrm{~kg}$, while in NPrR group it was $9.7 \pm 4.1 \mathrm{~kg}$.

Conclusions. Individuals that have been using smart devices for over 3 years and have dependency on smart devices have significantly lower active range of motion of the neck and neck flexor muscle strength than individuals who are at no risk of the dependency and individuals at high risk of the dependency on smart devices.

Keywords: smart devices, cervical spine, range of motion, muscles strength, function.

Gautas 20200908

Priimtas 20201020 